\title{
Corporate financialization's conservation and transformation: from Mark I to Mark II
}

\section{Tristan Auvray $^{1} \cdot$ Cédric Durand $^{1,2}(D)$ Joel Rabinovich ${ }^{3} \cdot$ Cecilia Rikap $^{4,5}$}

Received: 11 December 2020 / Accepted: 23 June 2021 / Published online: 15 July 2021

(c) The Author(s) 2021

\begin{abstract}
This paper argues that, as far as the investment behavior of non-financial corporations is concerned, the apparent continuity over the last four decades suggested by the corporate financialization label is misleading. Indeed, while the disconnection between profitability and investment is a robust stylized fact for most of the period, with cumulative detrimental consequences for labor, we contend that the underlying mechanisms changed meaningfully at the turn of the millennium. This contribution identifies-empirically and theoretically - two distinct successive corporate financialization regimes (Mark I and Mark II) and explains their evolutionary articulation. Financialization Mark I is characterized by the empowerment of financial actors: in a context of high interest rates and full-blown liberalization, diminishing retained earnings by non-financial corporations resulted in a dramatic slowdown of investment. Contrastingly, Financialization Mark II is characterized by a strongly established financial hegemony with new forms of intellectual and financial monopoly. In this configuration, interest rates are low and global value chains are deeply seated. This fuels rampant deflationary pressure, which changes the overall dynamic of the profit-investment nexus. Then, in Financialization Mark II, contrary to what occurred during Financialization Mark I, distributed profits are the consequence of slow investment.
\end{abstract}

Keywords Financialization regimes · Investment-profit nexus · Payout ·

Globalization: Intellectual monopoly · Asset managers

\section{Introduction}

The four last decades exhibited a puzzling concomitance of macrotendencies. Except for the United States (US) in the second half of the nineties, most developed economies experienced disappointing performances in terms of GDP

All authors have contributed equally

Cédric Durand

cedric.durand@unige.ch

Extended author information available on the last page of the article 
and productivity growth; investment was generally lackluster, but profitability improved, and stock market valuation skyrocketed at a historical high in 2020, in the middle of a pandemic.

This period was also characterized by a meaningful change in corporate governance. After decades of relative managerial autonomy, the shareholder value orientation (SVO) progressively asserted the primacy of equity holders among other stakeholders on legal and economic grounds. This followed a sharp rise in real interest rates after the generalization of restrictive monetary policies by central banks in the name of the fight against inflation at the turn of the eighties. In the meantime, a vast movement of internal and external liberalization of financial operations drastically increased financial assets' liquidity.

Overall, these self-reinforcing changes resulted in a new assertiveness of the claims of the financial community (banks, financial institutions, investment funds, and ultimate owners of assets...) and in a weakening of labor position, which suffered an increasing commodification and a relative devaluation vis-à-vis capital.

This evolution was dubbed, with many nuances, financialization (van der Zwan 2014). In addition to the commodification of multiple aspects of everyday life and the increasing penetration of financial motives, the disconnection of profits and accumulation has been a central issue in the literature (Durand and Gueuder 2018; Stockhammer 2004).

Here, the emphasis is on non-financial corporations' investment behavior and, in particular, the intricacies of what the literature refers to as the SVO (Aglietta 2000; Froud et al. 2000; Lazonick 2017; Lazonick and O'sullivan 2000). This paper deals with this specific dimension of financialization that we define as a shift in the uses of profits by non-financial corporations at the expense of overall productive investment. Our empirical inquiry covers the five biggest high-income economies (France, Germany, Japan, the UK, and the US) between 1980 and 2018. It consists of descriptive statistics built upon macroand microdatasets, in order to grasp dynamics occurring both at the country level and at the largest global firm level.

We argue that, as far as the investment behavior of non-financial corporations is concerned, the apparent continuity over the last four decades suggested by the corporate financialization label is misleading. Indeed, while the disconnection between profitability and investment is a robust stylized fact for most of the overall period, with cumulative detrimental consequences for labor, we contend that the underlying mechanisms changed meaningfully at the turn of the millennium.

This contribution aims to identify-empirically and theoretically - two distinct successive financialization regimes (Mark I and Mark II) and explain their evolutionary articulation.

We pick the year 2000 to distinguish between Mark I and Mark II. There is, indeed, a transition period between both financialization regimes; hence, the choice of this specific year for the caesura is to some extent arbitrary. In some respect, such as the institutional changes associated with the emergence of intellectual monopolies, Mark II started at least by the mid-1990s with the signature of The Agreement on Trade-Related Aspects of Intellectual Property 
Rights (TRIPS). Other features strengthened or became apparent since the Great Financial Crisis, such as rising concentration of equity funds, a growing importance of buybacks, and a sharper fall of the interest rate. Overall, we chose the year 2000 because it is a pivotal date along various dimensions that matters for our research. It signals the end of the digital economy boom in the US and the burst of the dot-com bubble, a sharp decrease of interest rates, the Doha agreement for global protection of intellectual property rights, and the entry of China into the WTO. ${ }^{1}$

Financialization Mark I received detailed attention from, among others, non-mainstream economists, sociologists, and geographers for the past quarter of a century. It is characterized by the empowerment of financial actors: in a context of high interest rates and full-blown liberalization, diminishing retained earnings by non-financial corporations resulted in a dramatic slowdown of investment with cascading negative effects for labor. Contrastingly, Financialization Mark II is characterized by a strongly established financial hegemony with new forms of intellectual and financial monopoly. In this configuration, interest rates are low and global value chains are deeply seated. This fuels rampant deflationary pressure, which changes the overall dynamic of the profit-investment nexus. We argue that in Financialization Mark II, contrary to what occurred during Financialization Mark I, distributed profits are the consequence of slow investment, not the cause.

To elaborate on this argument, the rest of the paper is organized as follows. Section 2 outlines the fields of literature that address the issue of sluggish investment in the corporate financialization era. Section 3 delineates conceptually the internal articulation of Financialization Mark I and Financialization Mark II and how they are evolutionarily related. Section 4 explains the operationalization of our categories and introduces our data sources. Section 5 presents descriptive statistics that document the continuities and differences of Financialization Mark I and II along several dimensions. Section 6 concludes with a discussion of these stylized facts and allows for a nuanced interpretation of the proposed conceptual framework.

\section{Sluggish investment in the financialization era}

For several decades, the literature has explored a wide array of debates about the disconnection between profits and investment in the context of financialization. As far as this paper is concerned, three dimensions are particularly relevant: (1) changes in corporate governance related to the rise of institutional investors and the affirmation of the primacy of the shareholder value; (2) changes in

\footnotetext{
1 The data presented and discussed in the paper are based on the 2000 caesura. However, we calculated and provided in the Appendix data with an alternative cutoff in 2008. With this date, the empirical distinction between Financialization Mark I and Mark II still holds.
} 
competition regimes; and (3) changes in demand growth and the formation of new demand regimes.

\subsection{The shareholder orientation of corporate governance and the rise of financial investors}

Shareholder value is nothing more than the net present value expected by investors in financial theory (Fisher 1930; Modigliani and Miller 1958). However, since the 1980s, the concept is used to legitimate changes in corporate governance both at the practical (Aglietta 2000; Froud et al. 2000) and theoretical level (Jensen 1986; Tirole 2006). In practice, it promoted a change in corporate strategies, shifting from a "retain and reinvest" model to a "downsize and distribute" model (Lazonick and O'sullivan 2000). From the beginning of the 1980s, the diffusion of this model was fostered by the rise of institutional financial investors and their empowerment as activist shareholders, first in the US and then in other rich economies (Gillan and Starks 2000; Jeffers and Plihon 2001).

From the 1970s on, a combination of various factors paved the way to what Hyman Minsky called "money manager capitalism" (e.g., Whalen, 2001). This multifold process of transformation of finance was unleashed by the deployment of asset management strategies oriented toward diversification in the 1970s (Montagne 2013) and the tightening of global monetary conditions, following the "1979 coup" by the US FED (Duménil and Lévy 2004). A decade later, the dismantlement of capital controls accelerated the diffusion of the SVO in coordinated market economies like France, Germany, and Japan (Ahmadjian and Robbins 2005; Lantenois and Coriat 2011; Morin 2000) and, more broadly, reinforced the power of finance due to the deepening of global liquidity (Orléan 1999).

High interest rates and the empowerment of financial investors resulted in a financial norm of high payouts to shareholders and a hurdle rate on productive investment projects (Boyer 2000). Empirical evidence from chief financial officer surveys' indicates that hurdle rates have been stable around 15\% since mid-1980s (Sharpe and Suarez 2020). Some authors point to the increase in financial payouts and the consequent reduction in retained earnings as the main driver of the diminishing ability of firms to invest (Duménil and Lévy 2004; Lazonick 2010, 2017). Others indicate a greater alignment of managers' and shareholders' preferences resulting in a greater emphasis on profitability over growth (Dallery 2009; Hein and Van Treeck 2010; Stockhammer 2004). Finally, some literature argues that outsourcing and offshoring of production support higher profits and payouts without investment in real assets (Auvray and Rabinovich 2019; Milberg 2008; Orhangazi 2018).

Empirically, the literature observes a negative correlation between investment in capital expenditures and financial payouts for the US (L. E. Davis 2018; Hecht 2014; Orhangazi 2008; Van Treeck 2008), the UK (Tori and Onaran 2018), France (Clévenot et al. 2010), and the European Union (Barradas 2017). Contrastingly, the hypothesis that investment in capital expenditures is crowded out by investment in financial (e.g., Krippner 2005) is not corroborated as a general trend (Auvray and Rabinovich 2019; Rabinovich 2019). 
In addition to the direct consequences of institutional investors' empowerment and shareholder value orientation on firms' investment behavior, the internal dynamic of competition between financial investors also led to significant changes in the ownership of non-financial corporations. As will be exposed next, this transformation at the level of the overall ownership structure also affects firms' investment.

\subsection{Competition regimes}

Compared to the "relatively quiet and uncompetitive 1960s" (Shleifer and Vishny 1991 , p. 54), the early 1980 s were characterized by slowing inflation, high interest rates, low profits, and increased foreign competition (Fligstein and Markowitz 1993; O’Sullivan 2001; Stein 2010). Competitive pressures increased with European and Asian catching-up vis-à-vis the US and, more broadly, with the liberalization of trade and capital flows and the deregulation of internal markets. To some extent, this context of coerced competition compelled firms to invest to survive, but the destructive impact of rising overcapacities played a more prominent and detrimental role on global investment (Brenner 2004; Crotty 2003; Koo 2018; Mazier et al. 1984; Petit 1999).

Intensifying competition characterized the beginning of the financialization era. However, since then a multidimensional process of monopolization gained steam.

In the early 1980s, the Bayh-Dole Act authorized US academic institutions to patent public-funded research results and to transfer this knowledge to private firms (Bok 2003; Orsi and Coriat 2006). This was the beginning of a massive process of knowledge enclosures that expanded globally via the WTO and trade agreements (Drahos 1995; Dreyfuss and Frankel 2014; Sell 2003, 2010).

Since the 2000s, empirical evidence shows that R\&D efforts and the accumulation of IPRs contributed to increasing profits and concentration (Calligaris et al. 2018; Dernis et al. 2019; Lambert 2019; Orhangazi 2018; Schwartz 2016). In this context, Pagano (2014 p. 1413) coined the term intellectual monopoly capitalism to account for a new stage in capitalism where the distribution of profits is increasingly explained by the centralization of intellectual property rights (IPRs) and defined intellectual monopoly as the "legal monopoly over some items of knowledge, which extends well beyond national boundaries."

In addition to the legal barriers built by IPRs, the rise of intangible assets and their economic properties (Corrado et al. 2012; Haskel and Westlake 2018) generated supplementary intellectual monopoly dynamics resulting from network effects, predatory practices in global innovation networks, the centralization of data, and the exploitation of differential returns to scale between in the context of value chains (Durand 2020; Durand and Milberg 2020; Foley 2013; Rikap 2020, 2021).

Overall, the detrimental effect of intellectual monopoly on investment is not limited to the fact that profits are channeled to firms largely protected from competition as it also prevents other firms to use and learn from privatized ideas and invest accordingly (Pagano and Rossi 2009).

Criticizing the recent literature on industrial concentration in the US, Davis and Orhangazi (2021) show that multiple trends and dynamics may be at work in 
different industries. However, using industry average, their data do not exclude the possibility of polarizing dynamics related to intellectual monopoly to take place. Precisely, they accept that firms may be gaining market power through increased use of intangibles and hence higher profits. Corroborating this conjecture and its potential detrimental effects for investment, empirical studies show that intangible accumulation is associated with market power that increases prices per unit of investment (Rabinovich 2020) and can be regarded as one possible cause of weak investment vis-à-vis profitability and valuation since the early 2000s in the US (Gutiérrez and Philippon 2016).

Besides, and with some overlapping with this intellectual monopolization, the transformation of the financial industry fueled a parallel dynamic of monopolization which is also considered to affect investment behavior.

Regarding asset management, the 2008 crisis has been the starting point of a huge centralization of savings in index funds and ETFs provided by the now Big Three asset managers, Blackrock, Vanguard, and State Street Global Advisors (Elhauge 2015; Fichtner et al. 2017, Fisch et al. 2018, Bebchuk and Hirst 2019; Anton et al. 2020, Fichtner and Heemskerk 2020). Their business model relies on expanding market shares thanks to low fees allowed by passive asset management and the dilution of fixed costs via economies of scale. They also took advantage of intellectual monopoly dynamics related to the development of "digital asset management platforms" (Haberly et al. 2019).

As a consequence of savings centralization, portfolio diversification by these giant investors reaches such a point that they hold important shares in each of the companies of their portfolio. In the US, they collectively hold $20 \%$ in each of the S\&P500 companies (Bebchuk and Hirst 2019). They also have important holdings in European and Japanese companies (Fichtner and Heemskerk 2020). This new trend challenges the short-term orientation of financial markets underlined by the literature because the exit option is not available for these investors that follow index composition changes. That is why Fichtner and Heemskerk (2020) label them "universal permanent owners."

Analyses indicate that the interest of these investors relies more on sectoral performance rather than individual firm performance (Anton et al. 2020; Antón et al. 2016; Azar et al. 2019). Accordingly, they foster managers to restrain to invest to avoid the uncertainties of intra-industry competition and their possible negative effects on overall sectoral profits. Moreover, rents from monopoly pricing and the increasing output price per investment mechanically restrain incentives to invest.

\subsection{Depressed demand growth and the formation of new demand regimes}

The deep interconnection and reinforcement between the set of neoliberal policies and weak investment has been widely noticed in the literature and is linked to several dimensions of the formation of demand regimes.

First, neoliberal policies implied a deteriorating income distribution given by a shift in power from labor to capital, both a de- (and also re-) regulation of various markets, a reduced direct economic involvement of the state given by privatization, 
and a shift in monetary policy going from full employment to price stability (Stockhammer 2008; Vercelli 2015).

The gap between productivity and wages increased for most of the period at the expense of labor in the US (Fleck et al. 2011; Lazonick 2014), but also in other OECD countries (Elgin and Kuzubas 2013; Erumban and Vries 2016).

Also for the US, Autor et al. (2017) showed that the rise of "superstar firms" that concentrate sales and are less labor-intensive than others contributes to explaining the fall in the labor share. Beyond the US, considering a group of OECD countries, Kohler et al. (2019) found that financial liberalization broadens exit options for firms and has negative effects on the wage share. More specifically, the negative link between wages and payout to shareholders was established for France, Germany, the UK, and the US (Alvarez 2015; Duenhaupt 2011; Lin and Tomaskovic-Devey 2013; Onaran and Guschanski 2018; Willman and Pepper 2020).

The impact on economic growth brought about by these distributive changes has been largely studied in the post-Keynesian literature built around the BhaduriMarglin models. Most of these studies have found wage-led demand regimes for the countries considered in this article (Hein and Vogel 2008; Onaran and Galanis 2014; Stockhammer et al. 2009). The combination of wage-led economic regimes with pro-capital distributional policies is what Stockhammer and Lavoie (2013) call "neoliberalism in practice"-in contrast with "neoliberalism in theory"- an unstable regime that has to rely on exogenous growth drivers.

This points to the second link between financialization and demand growth: recessionary tendencies were partly contained by external sources of demand. Government expenditures, consumer credit, residential investment, and exports (Girardi and Pariboni 2016) played a role: export-driven growth models characterize Nordic European countries while debt-driven appear more prominently in Anglo-Saxon and southern European countries (Hein 2012; Stockhammer 2009). Private debt has to some extent compensated for falling wages to support consumption patterns (Barba and Pivetti 2009; Frank et al. 2014).

In terms of public expenditures, their stagnation over GDP in OECD countries is a common feature since the 1980s up to the great financial crisis (Stockhammer 2008). In the immediate aftermath, their surge has been too short-lived and insufficient to overcome stagnation tendencies (House et al. 2020; Kohler and Stockhammer 2020).

Besides the specific dynamics of government expenditures, consumer credit, residential investment, and exports, the liberalization of trade and international financial flows has added a high degree of volatility and uncertainty to the economy that worsens the overall picture for demand and investment (Arestis and Glickman 2002; Orhangazi 2008).

Overall, this rapid outlook on the literature indicates that, since the 1980s, three main factors have affected adversely-and unevenly in space and time-non-financial firms' investment behavior. First, the empowerment of financial investors and the related shareholder value orientation. Second, monopolization dynamics related both to intellectual monopoly and a rapid concentration of ownership by gigantic asset managers. Third, more indirectly, the cumulative effects of neoliberal policies and the empowerment of shareholders have contributed to constrain workers' 


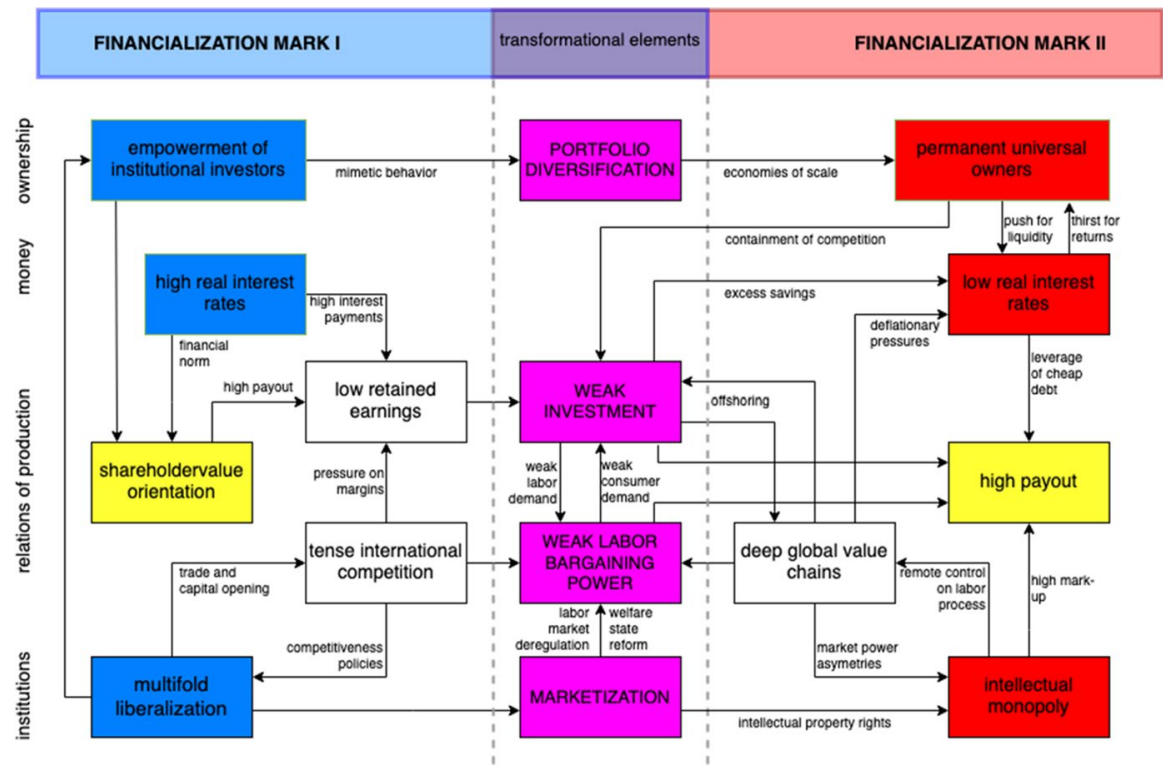

Fig. 1 From Financialization Mark I to Financialization Mark II

consumption, which depressed investment via the channels of managers anticipation and the formation of palliative sources of demand less favorable to investment.

The next section proposes a conceptual analysis of the transformation of these diverse dimensions of financialization and proposes an articulation of the shift between two distinctive phases or financialization regimes.

\section{Payout as a cause then as a consequence of low investment: a stylized story of financialization}

As far as the investment behavior of non-financial corporations is concerned, the apparent continuity along the last four decades suggested by the financialization label is misleading. Indeed, while the disconnection between profitability and investment is a robust stylized fact for most of the period, with cumulative detrimental consequences for labor (see Sections. 0 and 0), we contend that the underlying mechanisms changed meaningfully at the turn of the millennium.

This section outlines the conceptual framework we propose to explain the internal logic of two successive configurations of financialization. The labels Mark I and Mark II are freely adapted from the Schumpeterian literature on innovation (Malerba and Orsenigo 1995). It allows putting forward two distinctive logics contributing to a similar phenomenon, innovation in their case, profit without investment in ours.

The articulation proposed is highly stylized. However, it allows bringing together theoretical links that are usually set apart. Indeed, in addition to delineating the key defining relations of each regime, our conceptual framework proposes a theoretical 
articulation to account for the evolutionary shift from Financialization Mark I to Financialization Mark II. As exposed in Fig. 1, Financialization Mark I and Mark II are two regimes of accumulation characterized by slow investment and high financial payments, but they differ in their internal logic although they are evolutionarily related.

Financialization Mark I received detailed attention for already a quarter of a century (see Section 2). Financial deregulation paved the way for the rise of financial investors eager to extract payouts to maximize shareholder value in the short run. In this period, facing high inflationary pressure and widespread social unrests, the FED's decision to raise its key interest rates constrained most of the central banks to follow, which unleashed the revenge of finance. The resulting rise of real interest rates weighed on firms' internal finance. Moreover, high rates created a financial norm calling for higher distributed earnings to shareholders and acting as a hurdle rate to non-financial capital valorization.

This change of monetary conditions and the rise of a financial norm was a general constraint weighting on non-financial corporations' ability to fund their investment. This was all the more the case that competitive pressures grew tenser with industrial catching-up and the liberalization of trade and capital flows. Facing the primacy of a competitiveness agenda, management was more incentivized to focus on increased efficiency than on expansion.

In summary, in Financialization Mark I, the rationale of the surge in financial payments and the slowdown of investment responded to the combined influences of (i) the empowerment of financial investors at the expense of the unions, (ii) monetary tightening, and (iii) growing competitive pressure. Another outcome of Financialization Mark I was the deterioration of workers' bargaining power as a result of weaker labor demand and ongoing neoliberal reforms of the labor market and the welfare state. In turn, this contributed to depress investment through weaker consumer demand.

In the meantime, competition between financial institutions to attract fund management resulted in a general tendency toward portfolio diversification. Market movements explain more than $95 \%$ of the stock returns of US defined benefits pension funds over 1990-2008 (Aglietta et al. 2012), and about two-thirds of US professional equity funds are outperformed by the S\&P's 500-Stock Index from the 1970s to the 2000s (Burton G Malkiel 1995; Burton G. Malkiel 2005; Burton Gordon Malkiel 2019). Passive investment was consistently more profitable than active investment, which paved the way for the rapid development of mega index-tracking funds and the rapid consolidation of the sector.

At the institutional level, the deepening of marketization policies led to a more stringent definition and wider enforcement of IPRs and provided a generally supportive regulatory framework for the unfolding of emerging digital industries.

Financialization Mark II emerges out of these transformations. This new structural configuration is also characterized by weak investment and a further deterioration of labor bargaining power. However, several key relations took new prominent importance.

First globalization. Liberalization of trade and investment and technological breakthroughs allowed for a spectacular increase in the fragmentation of productive 
Table 1 Empirical dimensions of Financialization Mark I and II

\begin{tabular}{lll}
\hline & Financialization I & Financialization II \\
\hline & 1980-1999 & 2000-2018 \\
Investment & Low & Lower \\
Labor power & Weak & Weaker \\
Globalization & Expanding & High \\
Shareholders' payments & Expanding & High \\
Interest payments & High & Low \\
Competition & Competitive regime & Monopoly \\
\hline
\end{tabular}

processes. The resulting mobilization of cheap labor in the global south under the control of mostly northern lead firms was perfectly consistent with the reluctance to commit capital for investment and contributed to further weakening labor bargaining power and a deepening of the international intellectual division labor. The concentration of intellectual monopoly forces in the global north further entrenched lead firms' market power, allowing them to serve generous financial payout to their shareholders.

In parallel, weakening investment was less and less able to absorb global saving while deep and flexible global value chains fueled rampant deflationary pressure. This contributed to pushing down interest rates and encouraged central bankers to adopt drastically accommodative policies.

These monetary conditions, radically distinct from the first age of financialization, relieved firms from the hardship of high-cost debt, inciting them to leverage these favorable terms to increase their payments to shareholders. Overabundant liquidity depressed returns and pushed investors out of bond markets and toward equities, which contributed to the reinforcement of centralized investors' funds. At this level of ownership structure, the centralization of institutional ownership led to a new configuration where permanent universal investors at least partially control most of the listed firms. The extension of control through common ownership is essentially relevant at the sectoral level where funds can manage competition and limit investment to protect the overall quantity of profits.

With globalization, intellectual monopoly, and permanent universal investors, weak investment and high financial payments take place in a distinct economic logic. In Financialization Mark II, distributed profits are the consequence of slow investment, not the cause (as it was the case in Financialization Mark I).

During Financialization Mark I, high financial payout (payments to shareholders and interest) slowed investment due to the lack of internal funds. It was the empowerment of finance that drained retained earnings via interest payments and higher distributed profits. In Financialization Mark II, low investment and high payment to shareholders are symptomatic of a lack of sufficiently profitable opportunities for investment due to insufficient demand and monopoly power.

The rest of this paper will document to what extent this investment famine became the main driver of Financialization Mark II instead of the financial squeeze of firms' internal funds, characteristic features of Financialization Mark I. 
To assess the distinction between both Financialization regimes, we present and discuss stylized facts related to the six dimensions delineated in Table 1. If our stylized story is consistent and focusing on non-financial corporations, we should find that:

- The level of investment relative to profits further declined.

- Labor bargaining power cumulatively deteriorated.

- Payout to shareholders relative to profits expanded in the first period to attain a high level in the second.

- Globalization expanded, reaching a high level in the second period.

- Interest payments were high in the first but low in the second period.

- The competition regime dramatically shifted from generally increasing competitive pressure to a new situation characterized by intellectually (intangibles) driven monopolization and financial ownership centralization.

\section{Operationalizing our categories: scope, data, and sources}

To map the contrast between Financialization Mark I and Financialization Mark II, we empirically analyze the changes in the six dimensions outlined in Table 1.

The term investment refers to the accumulation of productive (tangible and intangible) capital by non-financial corporations. Labor bargaining power denotes the ability of workers to act collectively to set their income and to protect or improve their working conditions. Globalization refers to increasing trade relations, foreign direct operations, and international segmentation of productive processes. Shareholders' payments and interest payments refer to the two main forms of financial payments by non-financial corporations to financial entities. Finally, Competition refers to the configuration of the competitive struggle resulting both from operational forces and financial distribution of controlling stakes.

A difficulty in capturing these six dimensions results from the fact that financialization is a global phenomenon and not merely an international one. In a Bank of International Settlement (BIS) report, Avdjiev et al. (2018, p. 1) argue that the global reach of companies and ownership and the dispersion of economic activity (among others organized in global value chains) results in tension when it comes to data and policies, which are still determined at what the authors call "island" and "between islands" levels. The "island" metaphor refers to how the most used unit of analysis is the so-called economic area (a country, region or union). Starting from this perspective results in an approach to globalization in terms of transactions "between islands," losing sight of dynamics occurring at the global level. Therefore, a growing tension emerges "between the nature of the economic activity and the measurement system."

Since a global measurement system remains a blind spot, to partially overcome this tension, our analysis considered both macroeconomic level data and firm and ownership structure level data. This allowed us to move beyond methodological 
nationalism without losing the national dimension which, despite globalization, remains a relevant unit of analysis.

We focused on the major developed economies, namely, the US, the UK, France, Germany, and Japan from 1980 to 2018. When data were not available for the full period, we used a shorter series. We built summary indicators to present stylized facts in a condensed manner. The figures with full series were included in the appendix.

We are aware of the potential pitfalls involved in calculating averages from different countries, considering their institutional and economic variegation. For this reason, figures with country-level information are included in the appendix. Nonetheless, in line with our theoretical argument, these figures show that chosen countries tend to broadly conform to similar patterns for the selected variables. In the following analysis, we mention and discuss the few exceptions.

\subsection{Macroindicators at the country level}

At the macroeconomic level, we used OECD, World Bank, National Accounts, FRED, the IMF, BIS, United Nations, the US National Science Foundation, and the United States Patent and Trademark Office (USPTO) data to build stylized facts for the different dimensions of analysis that we are using to distinguish between the two phases of financialization. For each dimension, Table A1 (Appendix 1) presents the indicators we built and their corresponding data source.

To assess the evolution of investment, we included an indicator of tangible capital accumulation (gross fixed investment for non-financial corporations as a proportion of gross operating surplus) and an indicator of intangible capital accumulation. We defined the latter as intellectual property assets between years t 0 and year $t-1$ as a proportion of gross operating surplus in t0. A limitation of this variable is that we could only measure part of total intangible assets. Data on organizational capital and training was not available, so our intangible capital accumulation indicator only includes (i) computer software and database, (ii) entertainment, literary or artistic originals, and (iii) research and development.

In the case of labor bargaining power, we analyzed labor share-defined as the share of labor compensation in GDP — and unionization rates.

To study globalization, we tracked the evolution of trade as a percentage of GDP, imports from emerging and developing countries (1980-2018), and used Carballa et al. (2020) index for the GVC participation rate in 1995 and 2011, due to data availability. This index is defined as the sum of the non-primary product portion of domestic value-added in exports plus intermediate imports over GDP.

Shareholder payments were tracked by considering the evolution of non-financial corporations' net dividend payments and non-financial corporations' listed shares redemption. Due to data availability, Japan's series and 1990s figures for the US were proxied with the negative flow of listed shares issuance by non-financial corporations. In turn, we computed data for three variables concerning interest payments: the annual evolution of the real interest rate, non-financial corporations' net interest payments, and credit to non-financial corporations. 
Finally, our competition data at the macroeconomic level is focused on the emergence of intellectual monopoly capitalism. We considered the annual evolution of non-financial corporations' intellectual property assets as a share of total fixed assets, patents per researcher, and the ratio of the top 10 patent holders in total USPTO patents in 1995 and 2019. For patents per researcher, we used total researchers full-time equivalent for every country except for the USA since this variable was not available. We used instead individuals employed in science and engineering occupations. Additionally, we include information from the Executive Opinion Survey of the World Economic Forum on executives' opinion about the degree of intellectual property protection in their respective countries.

Summaries of all these variables with their corresponding sources and descriptions are available in Appendix 1 (Table A1) and Appendix 2 (Figures MAC1 to MAC15).

\subsection{Firm-level financial and ownership data}

We complemented the macroeconomic information with data from non-financial listed firms using Compustat North America and Compustat Global. Although these firms represent only a minority of the total number of companies, they play a significant role in all the dimensions we are covering.

We kept all active and inactive, publicly listed non-financial corporations incorporated in the counties we consider, excluding financial firms identified by the primary SIC codes from 6000 to 6799 . We used different starting dates based on the quality and availability of the information: for the USA, since 1980, and for the rest of the countries, 1998. Therefore, comparisons between the Financialization Mark I and II are done on an end-of-period basis. We converted all the information into dollars to add it up and compute all firms together.

Most of the financial information was retrieved directly from Compustat. This was the case of capital expenditures, operating income before depreciation, long-term debt, net payouts (purchase of common and preferred stock + cash dividends - sale of common and preferred stock), net interest payments (interest expense-interest income), intangible assets, and sales.

The only variable that was built rather than gathered directly was intangible investment, where we followed Peters and Taylor (2017, p. 256-257). It was calculated by adding two types of investment: organizational and knowledge investment.

For the European countries, a problem faced with the accounting data is that before the adoption of International Financial Reporting Standards (IFRS) in 2005, many European firms did not separate spending on SG\&A (Döttling et al. 2017). Before that, year values are therefore artificially low. Since Japan adopted IFRS very recently (Tsunogaya et al. 2015), we excluded it from intangible investment calculations.

We also used ownership information from Thomson Eikon to calculate the share of total outstanding stocks held by the "Big Three" (BlackRock, Vanguard, and State Street) among the ten most important shareholders in a replication of specific indexes for all countries-except Japan because we were not able to obtain 
information. We ape the indexes S\&P500 (for the USA), DAX30 (for Germany), FTS100 (for the UK), and CAC40 (for France) by taking the top 500, 30, 100, and 40 firms by sales in each year for those countries respectively and calculated the ownership by Big3 in those firms. To further assess "Big Three" concentration, we compared their Equity funds (from Pension and Investment) to the world market capitalization (World Bank data), and to the total world equity funds (Financial Stability Board data).

Finally, to give a further account of digital concentration, we analyzed the public cloud computing market. We retrieved figures for the size of data stored in the public cloud as a share of total data storage worldwide from IDC and market shares for top providers of public cloud Infrastructure as a Service (IaaS) from Statista. In the public cloud, firms and other organizations pay for what they use. Hence, market shares for IaaS can be considered as a proxy of data storage shares. We used these data to estimate the share of the data stored in each main public cloud provider vis$\grave{a}$-vis global data storage. Due to data availability, we compared figures for 2015 and 2018 , both for the public cloud market shares and the shares of total data storage worldwide that is stored in the public clouds of the top three providers (Amazon, Microsoft, and Google).

With these various databases, we were able to build firm-level indicators related to all the dimensions discussed in this article except those involving labor bargaining power and globalization. Information on employees and wages tends to be poor with many missing observations. Similarly, information on international activities is poor for the USA and non-existent for the rest of the countries. Anyway, this is not a significant limitation considering the availability of macroeconomic data for these same variables.

A summary of all these variables with their corresponding sources and descriptions is available in Appendix 1 (Tables A2-A3) and Appendix 3 (Figures MIC1-MIC9).

\section{Tracking Financialization Mark I and Mark II}

This section exposes the features exhibited by the descriptive statistics we compiled. They allow capturing the distinctiveness and similarities of Financialization Mark I and Mark II along the various dimensions we identified in our conceptual framework: investment, labor bargaining power, globalization, corporate finance (shareholder and interest payments), and competition.

\subsection{Investment}

The weakening in the investment-profit relation given by the alternative uses of funds at the expense of investment is maintained throughout Financialization Mark I and II. Fixed capital formation, using national accounts data, goes from $63.3 \%$ (1995-1999) to 59.4\% (2000-2018) of gross operating surplus. Similarly, intellectual capital formation decreases from 2.9 to $2.1 \%$ (Table 2). 
Table 2 Investment in Financialization Mark I and II

\begin{tabular}{llll}
\hline & Indicator & Mark I & Mark II \\
\hline Macrodata & Fixed capital formation & 63.3 & 59.4 \\
Average of country & NFCs, \% of GOS & $(1995-1999)$ & $(2000-2018)$ \\
& Intellectual capital formation & 2.9 & 2.1 \\
& NFCs, \% GOS & $(1996-1999)$ & $(2000-2017)$ \\
Firm-level data & Capital expenditures & 55.3 & 43.63 \\
All firms' average & NFCs, \% GOS & $(1999)$ & $(2018)$ \\
& Intangible investment & 43.5 & 44.3 \\
& NFCs, \% GOS & $(1999)$ & $(2018)$ \\
\hline
\end{tabular}

These broad averages hide some national specificities, especially the case of France who portrays a declining trend through Mark I but increasing during Mark II. In this case, the upward investment trend comes mostly from stagnant operating surplus. This can be linked to the creation of the Euro and the related lack of flexibility of exchange rates that dramatically affected France's competitiveness (Clevenot et al. 2016).

In the rest of the countries, the ratio increases post-2010 but does not reach its previous levels (Fig. 1MAC). In the case of intellectual capital formation, it drops in the aftermath of the dot-com bubble in Germany, France, the UK, and the USA. However, before and after that point in time, trends are more stable than with capital formation, and differences, smaller (Fig. 2MAC).

Similar figures built with firm-level data indicate the same pattern and have a further advantage, as it was discussed in the data section, of consolidating firms' activities worldwide. The comparison, this time on a year vs. year basis, still indicates lower capital expenditures: $55.26 \%$ vs. $43.63 \%$ when all firms are considered and $61.34 \%$ vs $42.59 \%$ when the average is computed on a national basis (Table 2).

In the case of intangibles' investments, the firm-level data shows a higher investment in Mark I compared to Mark II contrary to macrodata. We can attribute this to several reasons. First, calculations are different: only intellectual capital is considered in the national accounts whereas the firm-level definition is broader (and also more imprecise) as it takes a percentage of SG\&A for all firms. Second, R\&D tends to be very concentrated in the larger companies with the top 10 firms spending $15 \%$, top 50, 40\%, and top 100, 52\% of the total (European Commission 2019).

In any case, even if there is an increase in intangible investment due to the shift toward more intangible intensive economic processes and an increased assetization of knowledge, this rise is still modest and does not compensate for the decline of fixed capital investment. Overall, the trend of total investment (both fixed and intangibles) is clearly downward.

\subsection{Labor bargaining power}

A shared feature of Financialization Mark I and Mark II is the overall continuous weakening of labor position, which suffered an increasing commodification and a relative devaluation vis-à-vis capital (Table 3). 
Table 3 Labor in Financialization Mark I and II

\begin{tabular}{llcc}
\hline & Indicator & Mark I & \multicolumn{1}{l}{ Mark II } \\
\hline $\begin{array}{l}\text { Macrodata } \\
\begin{array}{c}\text { Average of } \\
\text { countries }\end{array}\end{array}$ & $\begin{array}{l}\text { Labor compensation } \\
(\% \text { GDP })\end{array}$ & $\begin{array}{c}61.1 \\
(1993-1999)\end{array}$ & $\begin{array}{c}60.2 \\
(2000-2018)\end{array}$ \\
& $\begin{array}{l}\text { Unionization rate } \\
\text { (\% employees) }\end{array}$ & $\begin{array}{c}25.4 \\
(1980-1999)\end{array}$ & $\begin{array}{c}17 \\
(2000-2018)\end{array}$ \\
\hline
\end{tabular}

Table 4 Globalization in Financialization Mark I and II

\begin{tabular}{llll}
\hline & Indicator & Mark I & Mark II \\
\hline $\begin{array}{l}\text { Macrodata } \\
\begin{array}{l}\text { Average of coun- } \\
\text { tries }\end{array}\end{array}$ & $\begin{array}{l}\text { Trade } \\
(\% \text { GDP) }\end{array}$ & $\begin{array}{l}35.9 \\
(1980-1999)\end{array}$ & $\begin{array}{l}\text { (2000-2018) } \\
\end{array}$ \\
& $\begin{array}{l}\text { Imports from emerging and developing } \\
\quad \text { countries } \\
\text { (\% total imports) }\end{array}$ & $\begin{array}{l}16.2 \\
(1980-1999)\end{array}$ & 27.1 \\
& $\begin{array}{l}\text { Participation in global value chains } \\
\text { (index) }\end{array}$ & $\begin{array}{l}\text { (2000-2018) } \\
(1995)\end{array}$ & 25.2 \\
& & & $(2011)$ \\
\hline
\end{tabular}

Beyond the general trend, the share of labor compensation in GDP shows a clear downward trend for all our selected countries throughout both periods excepting for the UK (Fig. 3MAC). In this respect, Onaran and Guschanski (2018) found that social government spending has an important effect on wage share determination in the UK and France. In the UK, social government spending rose from 1998 until 2013, which could at least partially explain labor's share recovery.

Unsurprisingly, given the evolution of the wage share in both periods, unionization shows a continuous downward trend (Fig. 4 MAC). The only exception was the case of Germany in the year 1990. However, it is already known that after the fall of the Berlin Wall Western Germany's unions expanded into the east taking over members from East Germany's state trade union which explains the 1990 bump (Fichter 1997; Schnabel and Wagner 2003). Since then, the unionization rate returned to its falling trend.

\subsection{Globalization}

Globalization has clearly expanded throughout the last decades as it is indicated in Table 4: all our chosen measures have higher averages in Mark II than in Mark I. In terms of international trade, not only levels are higher but also the rate of growth followed a similar path. Except for the USA, the comparison between the starting and last year of Mark I and Mark II shows a higher increase for the latter (Fig. 5MAC). The highest increases, on the other hand, are verified in France and Germany as a result of the development and further integration of the European Union.

The expansion has also been higher in Mark II than in Mark I for imports from emerging and developing countries (Fig. 6MAC). The aforementioned entry of China into the WTO plays a major role in the explanation of this trend. 
Table 5 Corporate finance in Financialization Mark I and II

\begin{tabular}{llll}
\hline & Indicator & Mark I & Mark II \\
\hline Macrodata & Net dividend payment & 18.3 & 20.4 \\
Average of country & NFCs, \% GOS & $(1995-1999)$ & $(2000-2017)$ \\
& Listed shares' redemption & n.a & 8.2 \\
& NFCs, \% GOS & & $(2003-2017)$ \\
& Long-term real interest rate & 4.3 & 1.3 \\
& & $(1980-1999)$ & $(2000-2018)$ \\
& Net interest payment & 14.5 & 9.3 \\
& NFCs, \% GOS & $(1980-1999)$ & $(2000-2017)$ \\
& Credit & 75.2 & 87.3 \\
Firm-level data & NFCs, \% GDP & $(1980-1999)$ & $(2000-2018)$ \\
& Long-term debt & 22.0 & 24.8 \\
& NFCs, \% total assets & $(1999)$ & $(2018)$ \\
& Net interest payment & 13.3 & 8.7 \\
& NFCs, \% operating income before depreciation & $(1999)$ & $(2018)$ \\
& Net payouts & 6.4 & 30.5 \\
& NFCs, \% operating income before depreciation & $(1999)$ & $(2018)$ \\
\hline
\end{tabular}

For participation in global value chains, we only compared two specific years. As it is shown in Fig. 7MAC, the increase in Mark II is verified for all countries but is especially pronounced for Germany due to the expansion of its industrial value chains eastward as the European trading block that has become increasingly regional, especially since the 2000s (World Bank 2020). Likewise, Japan verifies an increase, also associated with the expansion of a regional trading block, but in this case the East Asian and Pacific one.

\subsection{Corporate finance}

Important financial payments characterize both Financialization Mark I and Mark II. The distinctive feature of Financialization Mark I is the high level of real interest rate and net interest payment. Once the fight against inflation was won, the decrease of interest rate and interest payments was offset by the rise in dividends and share buybacks from the mid-1990s onwards, while US institutional investors spread the shareholder value orientation in a world without capital controls.

As shown in Table 5, macrodata provide clear figures for the decreasing role of interest payments in the investment squeeze, with real interest rate declining from 4.3 to $1.3 \%$ and net interest payments decreasing from 14.5 to $9.3 \%$ of gross operating surplus. However, macrodata indicates only a slight increase in net dividends' payments, going from 18.3 to $20.4 \%$ of GOS. Adding share buybacks approximated by share redemption to net dividend payments, the total payout of cash to shareholders increased from $23 \%$ of GOS in 2003 to $30 \%$ in 2018, which is much higher than the 1980s burden of interests. Such buybacks have been fueled by the growing leverage of non-financial corporations from 75 to $87 \%$ of GDP, made possible by 
low interest rates. Japan is an exception of this last trend explained by the burst of its asset price bubble at the beginning of the 1990s.

These numbers are very coherent with microdata, which show a strong rise in payouts to shareholders, from $6.4 \%$ in 1999 to $30.5 \%$ in 2018 , while net interest payments decrease from 13.3 to $8.7 \%$, the same orders of magnitude than macrodata.

Among the countries under consideration, the only outlier is France's decrease of dividends in macroeconomic data over the 2010s (Fig. 8MAC). This evolution is not consistent with the evolution of payments to shareholders (Fig. 3 Mic) nor with data from other sources. Detailed discussion of accounting methods (Garnier et al. 2015; Husson 2015, 2020) indicates that the decrease in macrodata is a statistical artifact related to methodological changes at the statistical institute and/or new accounting practices by transnational corporations.

\subsection{Competition}

Financialization Mark I and Mark II exhibit different competition regimes. The latter is characterized by an increase in market concentration (see Fig. 6MIC): within each country's top 500 non-financial corporations, the share of the sales of the top 30 grows. This general average is also verified for all countries but Japan.

To account for intellectual monopoly, we considered several variables. At the macrolevel, we analyzed the weight of intellectual property assets in relation to total fixed assets (Table 6). We found that it increased significantly in the second period vis-à-vis the first one with the only exception of the UK (Fig. 13MAC). This could be due to a change in the relative importance of different types of intangibles mainly from software (which is included in Fig. 13MAC) toward organizational capital and training (whose figures are not available for all the countries; thus, we could not include them in Fig. 13MAC) (O'Brien 2018).

We also tracked the evolution of patents per researcher showing that the rate increased for Financialization Mark II, which indicates an acceleration of the privatization of knowledge production. At the global level, the ratio of the top 10 patent holders in total USPTO patents increased from $9.6 \%$ in 1995 to $10.7 \%$ in 2019 . This suggests that privatization gets along with an increasing concentration of knowledge, as perceived by executives. Moreover, this is verified in all countries (Fig. 14MAC and Fig. 15MAC).

At the firm level, non-financial corporations' intangible assets as a share of total assets steadily grow during Financialization Mark II for the 5 countries, going from 9\% in 1999 to $22 \%$ in 2018 (Table 6 and Fig. 7MIC). Within intangibles, the concentration of data stands out in Financialization Mark II. The public cloud computing business is a case in point. According to IDC, data stored in the public cloud represented less than $5 \%$ of the worldwide data storage in 2010 . It jumped to $10 \%$ in 2015 and, by 2018, it was already around 20\%. As the share of data stored in the public cloud grew, concentration in this market intensified. As a result, our estimates indicate that the first three providers of infrastructure as a service on the public cloud (Amazon, Microsoft, and Google) concentrated around $4.8 \%$ of the global data stored worldwide in 2015 and $13.5 \%$ in 2018. 
Table 6 Investment in Financialization Mark I and II

\begin{tabular}{|c|c|c|c|}
\hline & Indicator & Mark I & Mark II \\
\hline \multirow[t]{4}{*}{$\begin{array}{l}\text { Macrodata } \\
\text { Average of country }\end{array}$} & Intellectual property assets $N F C s, \%$ of fixed assets & $\begin{array}{l}6.6 \\
(1980-1999)\end{array}$ & $\begin{array}{l}11.4 \\
(2000-2017)\end{array}$ \\
\hline & Patents per researcher & $\begin{array}{l}0.018 \\
(1996-1999)\end{array}$ & $\begin{array}{l}0.024 \\
(2000-2018)\end{array}$ \\
\hline & $\begin{array}{l}\text { Intellectual property protection (2011-2018) } \\
\text { Executives perception }\end{array}$ & & $\begin{array}{l}5.47 \\
(2011-2012) \\
5.88 \\
(2017-2018)\end{array}$ \\
\hline & Top 10 patent holders in total patents (USPTO) & $\begin{array}{l}9.6 \\
(1995)\end{array}$ & $\begin{array}{l}10.7 \\
(2019)\end{array}$ \\
\hline \multirow[t]{6}{*}{$\begin{array}{l}\text { Firm-level data } \\
\text { All firms' average }\end{array}$} & $\begin{array}{l}\text { Sales of top } 30 \mathrm{NFC} \\
\% \text { of top } 500\end{array}$ & $\begin{array}{l}28.5 \\
(1999)\end{array}$ & $\begin{array}{l}29.3 \\
(2018)\end{array}$ \\
\hline & $\begin{array}{l}\text { Intangible assets } \\
N F C s, \% \text { total assets }\end{array}$ & $\begin{array}{l}9.0 \\
(1999)\end{array}$ & $\begin{array}{l}22.0 \\
(2018)\end{array}$ \\
\hline & $\begin{array}{l}\text { Data concentration in the public cloud } \\
\text { Top } 3 \text { providers-share of global data storage }\end{array}$ & & $\begin{array}{l}4.8 \\
(2015) \\
13.5 \\
(2018)\end{array}$ \\
\hline & $\begin{array}{l}\text { Ownership by Big } 3 \\
\% \text { in top } 10 \text { institutional investors }\end{array}$ & $\begin{array}{l}2.1 \\
(1999)\end{array}$ & $\begin{array}{l}8.3 \\
(2018)\end{array}$ \\
\hline & $\begin{array}{l}\text { Concentration of Big } 3 \text { equity funds } \\
\% \text { world market capitalization }\end{array}$ & & $\begin{array}{l}9.5 \\
(2009-2018)\end{array}$ \\
\hline & $\begin{array}{l}\text { Concentration of Big } 3 \text { equity funds } \\
\% \text { world equity funds }\end{array}$ & & $\begin{array}{l}36.1 \\
(2009-2018)\end{array}$ \\
\hline
\end{tabular}

Finally, concentration at the market level and intellectual monopolization are accompanied in Financialization Mark II by concentration at the levels of ownership in comparison to Mark I. The share of ownership by the dubbed Big3 among the top ten institutional investors increases in each country (Table 8MIC). As expected, considering the literature (see Section 2.2), ownership concentration of the Big3 rises sharply for the US since the beginning of Financialization Mark II. It is followed by an increase in the UK figures and, since the 2008 crisis, the Big3 expand their share among the top ten institutional investors also in France and Germany. This concentration is the consequence of the concentration inside the financial industry: the Big 3 equity funds rise from 35 to $38 \%$ of the world equity funds, and from 8 to $12 \%$ of the world market capitalization between 2009 and 2018 (Fig. 9 MIC).

\section{Concluding remarks}

This paper contributed to the financialization literature concerned with non-financial corporations' investment behavior and, more specifically, to the analysis of a shift in the uses of profits by non-financial corporations at the expense of overall productive investment. We advanced a new interpretation of the changing internal logic of this dimension of financialization since the 1980s in three complementary ways. First, 
we distinguished two phases, namely Mark I and Mark II. Second, we proposed a conceptual articulation of their succession. And third, we documented the specific features of these two phases and the evolutionary process which supports them. We provided a wide array of descriptive statistics at the macro- and firm levels in support of our argument for the five biggest high-income countries and their listed firms for the period 1980-2018.

Our main argument is that during Financialization Mark I, the reduction of the share of profits used to invest is driven by pressure on firms' internal funds due to a rising cost of debt, rising shareholder claims, and uncertainty related to intensifying competition. On the contrary, monopolization tendency characterizes Financialization Mark II. Growing monopoly power has a twofold origin. On the one hand, it is explained by market power in global value chains, centralization of intangible assets, and growing privatization of knowledge. On the other hand, it is also expressed in the centralization of ownership rights by institutional investors specialized in ETF and index trading funds. This monopolization turned upside down the logic of corporate financialization. In Financialization Mark II, slow investment is the result of a lack of sufficiently profitable opportunities when it was the consequence of the lack of internal funds in the first period.

One important additional contribution is that we conceptualized this shift from Mark I to Mark II as the consequence of an evolutionary process through three main transformational dimensions. First, the empowerment of financial investors in the early phase paved the way to an internal competition within the financial industry that resulted in a very rapid concentration as a result of scale economies related to the implementation of portfolio diversification strategy. Second, sluggish investment favored an increasing reliance on foreign supplies in developing countries and a weakening of labor bargaining power which further depressed demand, constraining monetary authorities to adopt a very accommodative stance to try to stimulate economic activity and contain financial instability. The international segmentation of productive processes also allowed for an increasing polarization of knowledge in the international division of labor. Third, deregulation policies contributed to depress demand-then investment-via the deterioration of labor position and favored increasing privatization, which legitimated the global expansion of IPRs, closing innovation possibilities and investment venues while securing rents for lead firms.

This general story is corroborated by the stylized facts we presented. However, several aspects must be refined, nuanced, and strengthened, opening a stimulating research agenda. First, our overall argument does not allow for institutional diversity. This is related to our willingness to emphasize the global nature of the transformation. Nonetheless, rhythms and positions in this transformative unfolding of financialization are uneven in terms both of countries, sectors, and firms. One can for example mention the case of France that did not follow the general pattern of decreasing investment (as a share of profits) since the 2000s.

Another limitation of this article is that the plausibility of our story and the stylized facts we provided do not exhaust possible interpretations. For example, we emphasized the lack of growth opportunity in Mark II in comparison to Mark I. However, the fact that the financial constraint was relaxed in Mark II-with very accommodating credit conditions-does not preclude the possibility that growth 
opportunity was also missing in Mark I. To what extent both the absence of growth opportunity and strain on internal funds could have been combined in Mark I should be the object of future investigations. Whatever the answer, our point is that the decline in interest rates and increasing monopolization indicate that the lack of growth opportunity, relatively to the strain on internal funds, is a more important factor in Mark II than in Mark I. This limitation suggests nonetheless that further empirical exploration of the reversal of the causal links we proposed would be a welcomed follow-up of this paper.

This follow-up investigation could also include the evolutionary effect of corporate taxing systems and tax havens favoring monopolization and corporate financialization. For example, the most profitable firms and intangible intensive US firms tend to keep their offshored savings in US treasury and corporate bonds, collecting financial rents and taking debt in the US to pay to shareholders (Bryan et al. 2017; Pozsar 2018). This leads to an effective regressive corporate tax structure (Hager and Baines 2020), with far reaching consequences for policy making and competition dynamics.

Moving beyond listed corporations, future investigations could integrate venture capital and start-ups into our framework. Two interrelated phenomena should be considered. On the one hand, large corporations' acquisitions have pervasive effects on venture capital generating what Kamepalli et al. (2020) dubbed a "kill zone." On the other hand, it is worth noting that big corporations ${ }^{2}$ and major individual shareholders from big tech corporations are engaging in venture capitalism (Bradshaw and Thomas 2020).

Finally, future research should also consider the place of China in the overall picture we have presented. While some of the features of this story seem to fit for China as well (such as the rise of intellectual monopoly capitalism), others are the other side of our story (for instance, the effects of globalization).

In terms of policy implications, considered in isolation, financial reforms such as corporate governance reforms, changes in dividends taxation, or financial regulation will not be enough to deal with the mounting contradictions resulting from four decades of an increasingly loose relation between profits and investment. To tackle the issue of the inadequate level of investment vis-à-vis profits and, incidentally, the issue of its quality (among others considering ecological effects), both regulation and/or control over intellectual and financial monopoly and the buildup of investment planning capabilities need to be considered, taking into account their international ramifications.

Neoliberalism was a success of capitalist classes as marketization, privatization, and light-touch regulation of finance contributed to drastically rebalance bargaining power in their favor, at the expense of labor. However, as Marx early on observed, in its thrive toward universality, capital "encounters barriers in its own nature" (Marx 1858, sec. Notebook IV - The Chapter on Capital). The transformations of corporate financialization from Mark I to Mark II illustrate this tendency. The unfolding

\footnotetext{
${ }^{2}$ For instance, Amazon provides Amazon Web Services credit to promising startups as a form of venture capital (Amazon 2020).
} 
of financialization created new internal obstacles to the process of capitalist accumulation. Tackling them and promoting a sustainable and just mode of development will require to move beyond monetary, fiscal, or regulatory policies and to retool states' capacities in order to allow public action in the realm of production.

Supplementary Information The online version contains supplementary material available at https://doi. org/10.1007/s43253-021-00045-4.

Funding Open Access funding provided by Université de Genève.

Open Access This article is licensed under a Creative Commons Attribution 4.0 International License, which permits use, sharing, adaptation, distribution and reproduction in any medium or format, as long as you give appropriate credit to the original author(s) and the source, provide a link to the Creative Commons licence, and indicate if changes were made. The images or other third party material in this article are included in the article's Creative Commons licence, unless indicated otherwise in a credit line to the material. If material is not included in the article's Creative Commons licence and your intended use is not permitted by statutory regulation or exceeds the permitted use, you will need to obtain permission directly from the copyright holder. To view a copy of this licence, visit http://creativecommons.org/licen ses/by/4.0/.

\section{References}

Aglietta M (2000) Shareholder value and corporate governance: some tricky questions. Economy and Society 29(1):146-159

Aglietta M, Brière M, Rigot S, Signori O (2012) Rehabilitating the role of active management for pension funds. Journal of Banking and Finance 36(9):2565-2574

Ahmadjian CL, Robbins GE (2005) A clash of capitalisms: foreign shareholders and corporate restructuring in 1990s Japan. American Sociological Review 70(3):451-471

Alvarez I (2015) Financialization, non-financial corporations and income inequality: the case of France. Socio-Economic Review 13(3):449-475

Amazon (2020) Small business success in challenging times. 2020 AMAZON SMB IMPACT REPORT. Amazon.

Anton M, Azar J, Gine M, Lin LX (2020) Beyond the target: M\&A decisions and rival ownership. Available at SSRN 3226390.

Antón M, Ederer F, Giné M, Schmalz M (2016) Research: index funds are fueling out-of-whack CEO pay packages. Harvard Business Review. https://hbr.org/2016/10/research-index-funds-are-fueling-outof-whack-ceo-pay-packages. Accessed Dec 2020

Arestis P, Glickman M (2002) Financial crisis in Southeast Asia: dispelling illusion the Minskyan way. Cambridge Journal of Economics 26(2):237-260

Autor D, Dorn D, Katz LF, Patterson C, Van Reenen J (2017) Concentrating on the fall of the labor share. American Economic Review 107(5):180-185

Auvray T, Rabinovich J (2019) The financialisation-offshoring nexus and the capital accumulation of US non-financial firms. Cambridge Journal of Economics 43(5):1183-1218

Avdjiev S, Everett M, Lane PR, Shin HS (2018) Tracking the international footprints of global firms. BIS Quarterly Review, March.

Azar J, Raina S, Schmalz MC (2019) Ultimate ownership and bank competition. Available at SSRN 2710252.

Barba A, Pivetti M (2009) Rising household debt: its causes and macroeconomic implications-a longperiod analysis. Cambridge Journal of Economics 33(1):113-137

Barradas R (2017) Financialisation and real investment in the European Union: beneficial or prejudicial effects? Review of Political Economy 29(3):376-413

Bebchuk LA, Hirst S (2019) The specter of the giant three (No. 0898-2937) National Bureau of Economic Research.

Bok D (2003) Universities in the marketplace. Princeton University Press 
Boyer R (2000) Is a finance-led growth regime a viable alternative to fordism? A Preliminary Analysis Economy and Society 29(1):111-145

Bradshaw T, Thomas D (2020, November 30) Global tech founders back London-based start-up fund. Financial Times. https://www.ft.com/content/bbf74cdd-18a0-4811-8d2e-59cfb83c213a

Brenner R (2004) The economics of global turbulence. Verso

Bryan D, Rafferty M, Wigan D (2017) Capital unchained: finance, intangible assets and the double life of capital in the offshore world. Review of International Political Economy 24(1):56-86

Calligaris S, Criscuolo, C, Marcolin, L (2018) Mark-ups in the digital era (OECD Science, Technology and Industry Working Papers) OECD.

Carballa Smichowski B, Durand C, Knauss S (2020) Participation in global value chains and varieties of development patterns. Cambridge Journal of Economics 45(2):271-294

Clevenot M, Duwicquet V, Mazier J (2016) Quand les crises reviennent... Paris. Económica.

Clévenot M, Guy Y, Mazier J (2010) Investment and the rate of profit in a financial context: the french case. International Review of Applied Economics 24(6):693-714

Corrado CA, Haskel J, Iommi M, and Jona Lasinio C (2012) Intangible capital and growth in advanced economies: measurement and comparative results.

Crotty J (2003) The neoliberal paradox: the impact of destructive product market competition and impatient finance on nonfinancial corporations in the neoliberal era. Review of Radical Political Economics 35(3):271-279

Dallery T (2009) Post-keynesian theories of the firm under financialization. Review of Radical Political Economics 41(4):492-515

Davis L (2018) Financialization and the non-financial corporation: an investigation of firm-level investment behavior in the United States. Metroeconomica 69(1):270-307

Davis L, Orhangazi Ö (2021) Competition and monopoly in the U.S. economy: what do the industrial concentration data show? Competition and Change, 25(1):3-30.

Dernis H, Gkotsis P, Grassano N, Nakazato S, Squicciarini M, van Beuzekom B, Vezzani A (2019) World Corporate Top R\&D investors: Shaping the future of technologies and of AI (EUR 29831) Joint Research Centre and OECD report.

Döttling R, Gutierrez Gallardo G, Philippon T (2017) Is there an investment gap in advanced economies? If so, why? https://ssrn.com/abstract=3002796. Accessed Dec 2020

Drahos P (1995) Global property rights in information: the story of TRIPS at the GATT. Prometheus 13(1):6-19

Dreyfuss R, Frankel S (2014) From incentive to commodity to asset: how international law is reconceptualizing intellectual property. Michigan Journal of International Law 36(4):557-602

Duenhaupt P (2011) The impact of financialization on income distribution in the USA and Germany: a proposal for a new adjusted wage share. IMK Working Paper.

Duménil G, Lévy D (2004) Capital resurgent: roots of the neoliberal revolution. Harvard University Press

Durand C (2020) Technoféodalisme: Critique de l'économie numérique. Zones.

Durand C, Gueuder M (2018) The profit-investment nexus in an era of financialisation, globalisation and monopolisation: a profit-centred perspective. Review of Political Economy 30(2):126-153

Durand C, Milberg W (2020) Intellectual monopoly in global value chains. Review of International Political Economy 27(2):404-429

Elhauge E (2015) Horizontal shareholding. Harv L Rev 129:1267

Elgin C, Kuzubas TU (2013) Wage-productivity gap in OECD economies. Economics: The Open-Access, Open-Assessment E-Journal, 7(2013-21):1-21.

Erumban A, Vries K de (2016) Wage-productivity growth gap: an analysis of industry data. 16-01.

European Commission (2019) EU R\&D SCOREBOARD. European Commission.

Fichter M (1997) Trade union members: a vanishing species in post-unification Germany? German Studies Review 20(1):83-104

Fichtner J, Heemskerk EM (2020) The new permanent universal owners: index funds, patient capital, and the distinction between feeble and forceful stewardship. Economy and Society 49(4):493-515

Fichtner J, Heemskerk E, Garcia-Bernardo J (2017) Hidden power of the Big Three? Passive index funds, re-concentration of corporate ownership, and new financial risk. Bus Polit 19(2):298-326. https:// doi.org/10.1017/bap.2017.6

Fisher I (1930) Theory of interest: as determined by impatience to spend income and opportunity to invest it. Augustusm Kelly Publishers, Clifton

Fleck S, Glaser J, Sprague S (2011) The compensation-productivity gap: a visual essay. Monthly Labor Review 134(1):57-69 
Fligstein N, Markowitz L (1993) Financial reorganization of American corporations in the 1980s. In WJ Wilson, Sociology and the Public Agenda, Sage Publications:185-206

Foley DK (2013) Rethinking financial capitalism and the "information" economy. Review of Radical Political Economics 45(3):257-268

Frank RH, Levine AS, Dijk O (2014) Expenditure cascades. Review of Behavioral. Economics $1(1-2): 55-73$

Froud J, Haslam C, Johal S, Williams K (2000) Shareholder value and financialization: consultancy promises, management moves. Economy and Society 29(1):80-110

Garnier O, Mahieu R, Villetell, JP (2015) Coût du capital. Rapport du groupe de travail. Conseil national de l'information statistique. https://www.cnis.fr/wp-content/uploads/2017/10/RAP_2015_139_ cout-du-capital.pdf. Accessed Dec 2020

Gillan SL, Starks LT (2000) Corporate governance proposals and shareholder activism: the role of institutional investors. Journal of Financial Economics 57(2):275-305

Girardi D, Pariboni R (2016) Long-run effective demand in the US economy: an empirical test of the Sraffian supermultiplier model. Review of Political Economy 28(4):523-544

Gutiérrez G, Philippon T (2016) Investment-less growth: an empirical investigation. National Bureau of Economic Research.

Haberly D, MacDonald-Korth D, Urban M, Wójcik D (2019) Asset management as a digital platform industry: a global financial network perspective. Geoforum 106:167-181

Hager SB, Baines J (2020) The tax advantage of big business: how the structure of corporate taxation fuels concentration and inequality. Politics and Society 48(2):275-305

Haskel J, Westlake S (2018) Capitalism without capital: the rise of the intangible economy. Princeton University Press

Hecht J (2014) Is net stock issuance relevant to capital formation? Comparing heterodox models of firmlevel capital expenditures across the advanced and largest developing economies. Cambridge Journal of Economics 38(5):1171-1206

Hein E (2012) The macroeconomics of finance-dominated capitalism-and its crisis. Edward Elgar

Hein E, Van Treeck T (2010) Financialisation and rising shareholder power in Kaleckian/Post-Kaleckian models of distribution and growth. Review of Political Economy 22(2):205-233. https://doi.org/10. 1080/09538251003665628

Hein E, Vogel L (2008) Distribution and growth reconsidered: empirical results for six OECD countries. Cambridge Journal of Economics 32(3):479-511

House CL, Proebsting C, Tesar LL (2020) Austerity in the aftermath of the great recession. Journal of Monetary Economics 115:37-63

Husson M (2015) Sur la mesure des dividendes (No. 88; Note Nussonet) hussonet.free.fr/cnis715.pdf

Husson M (2020) Où sont passés les dividendes (bis) ? (No. 132; Note Nussonet). http://hussonet.free.fr/ div2019.pdf. Accessed Dec 2020

Jeffers E, Plihon D (2001) Investisseurs institutionnels et gouvernance des entreprises. Revue D'économie Financière 63(3):137-152

Jensen MC (1986) Agency costs of free cash flow, corporate finance, and takeovers. The American Economic Review 76(2):323-329

Kamepalli SK, Rajan R, Zingales L (2020) Kill zone. National Bureau of Economic Research.

Kohler K, Guschanski A, Stockhammer E (2019) The impact of financialisation on the wage share: a theoretical clarification and empirical test. Cambridge Journal of Economics 43(4):937-974

Kohler K, Stockhammer E (2020) Growth models in advanced countries before and after the 2008 crisis: competitiveness, financial cycles and austerity.

Koo R (2018) The other half of macroeconomics and the fate of globalization. John Wiley and Sons

Krippner GR (2005) The financialization of the American economy. Socio-Economic Review 3(2):173-208

Lambert TE (2019) Monopoly capital and innovation: an exploratory assessment of R\&D effectiveness. International Review of Applied Economics, 1-14.

Lantenois C, Coriat B (2011) Investisseurs institutionnels non-résidents, corporate governance et stratégies d'entreprise. Évaluation et analyse à partir d'un panel de firmes françaises et allemandes (1999-2007) Revue d'économie Industrielle, 134, 51-84.

Lazonick W (2010) Innovative business models and varieties of capitalism: financialization of the U.S. corporation. Business History Review, 84(04):675-702.

Lazonick W (2014) Profits without prosperity. Harvard Business Review 92(9):46-55 
Lazonick W (2017) The functions of the stock market and the fallacies of shareholder value. Corporate Governance in Contention, 117-151.

Lazonick W, O'sullivan M (2000) Maximizing shareholder value: a new ideology for corporate governance. Economy and Society 29(1):13-35

Lin KH, Tomaskovic-Devey D (2013) Financialization and US income inequality, 1970-2008. American Journal of Sociology 118(5):1284-1329

Malerba F, Orsenigo L (1995) Schumpeterian patterns of innovation. Cambridge Journal of Economics 19(1):47-65

Malkiel BG (1995) Returns from investing in equity mutual funds 1971 to 1991 . The Journal of Finance 50(2):549-572

Malkiel BG (2005) Reflections on the efficient market hypothesis: 30 years later. Financial Review 40(1):1-9

Malkiel BG (2019) A random walk down Wall Street: the time-tested strategy for successful investing. W.W. Norton and Company.

Marx K (1858, 1939) Grundrisse 08. Marxists.Org. https://www.marxists.org/archive/marx/works/1857/ grundrisse/ch08.htm. Accessed Dec 2020

Mazier J, Basle M, Vidal JF (1984) Quand les crises durent...Paris: Economica.

Milberg W (2008) Shifting sources and uses of profits: sustaining US financialization with global value chains. Economy and Society 37(3):420-451

Modigliani F, Miller MH (1958) The cost of capital, corporation finance and the theory of investment. The American Economic Review 48(3):261-297

Montagne S (2013) Investing prudently: how financialization puts a legal standard to use. Sociologie Du Travail 55:e48-e66

Morin F (2000) A transformation in the French model of shareholding and management. Economy and Society 29(1):36-53

O'Brien R (2018) Experimental estimates of investment in intangible assets in the UK: 2015. UK Office for National Statistics.

Onaran Ö, Galanis G (2014) Income distribution and growth: a global model. Environment and Planning, 46(10).

Onaran Ö, Guschanski A (2018) The causes of falling wage share: sectoral and firm level evidence from developed and developing countries-what have we learned?

Orhangazi Ö (2008) Financialisation and capital accumulation in the non-financial corporate sector: a theoretical and empirical investigation on the US economy: 1973-2003. Cambridge Journal of Economics 32(6):863-886

Orhangazi Ö (2018) The role of intangible assets in explaining the investment-profit puzzle. Cambridge Journal of Economics 43(5):1251-1286

Orléan A (1999) Le pouvoir de la finance. Éditions Odile Jacob.

Orsi F, Coriat B (2006) The new role and status of intellectual property rights in contemporary capitalism. Competition and Change 10(2):162-179

O'Sullivan M (2001) Contests for corporate control: corporate governance and economic performance in the United States and Germany (Publ. new as paperback) Oxford Univ. Press.

Pagano U (2014) The crisis of intellectual monopoly capitalism. Cambridge Journal of Economics 38(6):1409-1429

Pagano U, Rossi MA (2009) The crash of the knowledge economy. Cambridge Journal of Economics 33(4):665-683

Peters RH, Taylor LA (2017) Intangible capital and the investment-q relation. Journal of Financial Economics 123(2):251-272

Petit P (1999) Structural forms and growth regimes of the post-Fordist era. Review of Social Economy 57(2):220-243

Pozsar Z (2018) Repatriation, the echo-taper and the€/\$ basis. Global Money Notes, 11.

Rabinovich J (2019) The financialization of the non-financial corporation. A critique to the financial turn of accumulation hypothesis. Metroeconomica, 70(4):738-775.

Rabinovich J (2020) Financialisation and the 'supply-side'face of the investment-profit puzzle. Journal of Post Keynesian Economics. https://doi.org/10.1080/01603477.2020.1734463

Rikap C (2020) Amazon: a story of accumulation through intellectual rentiership and predation. Competition and Change. https://doi.org/10.1177/1024529420932418

Rikap C (2021) Capitalism, power and innovation. Routledge, Intellectual Monopoly Capitalism uncovered 
Schnabel C, Wagner J (2003) Trade union membership in Eastern and Western Germany: convergence or divergence?

Schwartz HM (2016) Wealth and secular stagnation: the role of industrial organization and intellectual property rights. The Russell Sage Foundation Journal of the Social Sciences 2(6):226-249

Sell SK (2003) Private power, public law: the globalization of intellectual property rights. Cambridge University Press

Sell SK (2010) TRIPS was never enough: vertical forum shifting, FTAS, ACTA, and TPP. J Intell Prop 1 $18: 447$

Sharpe SA, Suarez GA (2020) Why isn't business investment more sensitive to interest rates? Evidence from Surveys Management Science 67(2):720-741

Shleifer A, Vishny RW (1991) Takeovers in the'60s and the'80s: evidence and implications. Strategic Management Journal 12(S2):51-59

Stein J (2010) Pivotal decade: how the United States traded factories for finance in the seventies. Yale University Press

Stockhammer E (2004) Financialisation and the slowdown of accumulation. Cambridge Journal of Economics 28(5):719-741

Stockhammer E (2008) Some stylized facts on the finance-dominated accumulation regime. Competition and Change 12(2):184-202

Stockhammer E (2009) The finance-dominated accumulation regime, income distribution and the present crisis. Papeles De Europa 19:58-81

Stockhammer E, Lavoie M (2013) Wage-led growth: concept, theories and policies. In M Lavoie and E Stockhammer (Eds.):Wage-led Growth: An Equitable Strategy for Economic Recovery:13-39. Springer.

Stockhammer E, Onaran Ö, Ederer S (2009) Functional income distribution and aggregate demand in the Euro area. Cambridge Journal of Economics 33(1):139-159

Tirole J (2006) The theory of corporate finance. Princeton University Press

Tori D, Onaran Ö (2018) The effects of financialization on investment: evidence from firm-level data for the UK. Cambridge Journal of Economics 42(5):1393-1416

Tsunogaya N, Hellmann A, Scagnelli SD (2015) Adoption of IFRS in Japan: challenges and consequences. Pacific Accounting Review.

van der Zwan N (2014) Making sense of financialization. Socio-Economic Review 12(1):99-129

Van Treeck T (2008) Reconsidering the investment-profit nexus in financed-led economies: an ARDLbased approach. Metroeconomica 59(3):371-404

Vercelli A (2015) The neoliberal trajectory, the Great Recession and sustainable development. In P Arestis M Sawyer (Eds.):Finance and the Macroeconomics of Environmental Policies (pp. 37-73) Springer.

Whalen CJ (2001) Integrating Schumpeter and Keynes: Hyman Minsky's theory of capitalist development. Journal of Economic Issues 35(4):805-823

Willman P, Pepper A (2020) The role played by large firms in generating income inequality: UK FTSE 100 pay practices in the late twentieth and early twenty-first centuries. Economy and Society 49(4):516-539

World Bank (2020) World Development Report. World Bank. 


\section{Authors and Affiliations}

\section{Tristan Auvray $^{1}$ - Cédric Durand ${ }^{1,2}\left([) \cdot\right.$ Joel Rabinovich ${ }^{3} \cdot$ Cecilia Rikap $^{4,5}$}

Tristan Auvray

tristan.auvray@univ-paris13.fr

Joel Rabinovich

joel.rabi@gmail.com

Cecilia Rikap

ceciliarikap@gmail.com

1 CEPN, Université Sorbonne Paris Nord, Villetaneuse, France

2 Département d'Histoire Économie et Société, Université de Genève, Genève, Switzerland

3 Leeds University Business School, Leeds, United Kingdom

4 Consejo Nacional de Investigaciones Científicas y Ténicas (CONICET), Buenos Aires, France

5 CEPED, IRD/Université de Paris, Paris, France 